\title{
MIGRAÇÕES E LITERATURA INFANTOJUVENIL: BREVE PERCURSO SOBRE OBRAS E LEITURAS ${ }^{1}$
}

\section{MIGRATIONS AND CHILDREN AND YOUNG-ADULT LITERATURE: OVERVIEW OF WORKS AND READING}

\author{
Darlize Teixeira de Mello* \\ Iara Tatiana Bonin ${ }^{* *}$ \\ Rosa Maria Hessel Silveira ${ }^{* * *}$
}

\begin{abstract}
RESUMO:
Considerando o papel da literatura na recriação da experiência humana e no alargamento de horizontes dos leitores, o artigo tem dois objetivos: 1. realizar breve análise de sete títulos para crianças e jovens, publicados a partir de 2011 no Brasil, os quais têm como temática central a migração; 2. analisar alguns aspectos de uma sessão de leitura compartilhada de um dos livros apresentados "A viagem" de Francesca Sanna - com uma turma de $5^{\circ}$ ano de escola pública de Porto Alegre, assim como algumas produções textuais e imagéticas das crianças. As análises realizadas, através da metodologia da análise textual contextualizada, permitiram constatar a proliferação de obras literárias infantojuvenis sobre o tema, e a produtividade da leitura literária de obras nele inspiradas, bem como das negociações feitas entre as experiências pessoais dos alunos, por um lado, e o texto e as imagens do livro trabalhado, por outro.
\end{abstract}

Palavras-chave: Migração. Literatura infantojuvenil. Leitura. Anos iniciais. Negociações de sentidos

\begin{abstract}
Upon recognising literature role in recreating the human experience and in widening readers' range of perception, this paper aims to provide short analysis of seven titles for children and youngsters published from 2011 on in Brazil, which has the migration as its subject matter. It also aims to analyse a reading session of one the following books - Francesca Sanna's A Viagem - with a class in the year five of the primary school in a public school at Porto Alegre, as well as some textual and imagetic productions by children related to the work. The analyses, through the contextualized textual analysis methodology, allowed us to look at the propagation of children and young-adult literature about the subject matter and productivity of literary reading of works inspired in such subject upon analysing negotiations among students' own experiences and text and images in the working book.
\end{abstract}

Keywords: Migration. Children and young-adult literature. Reading. Early-year groups. Meaning negotiations

\footnotetext{
${ }^{1}$ O presente artigo é resultado de estudos e análises de dados de pesquisa empírica que integram o Projeto "Percursos e representações da infância em livros para crianças - estudo de obras e leituras", realizado com apoio do CNPq.

"Mestra e Doutora em Educação pela UFRGS. Professora da Universidade Luterana do Brasil.

"Mestra em Educação pela UNB e Doutora em Educação pela UFRGS. Professora da Universidade Luterana do Brasil.

*** Mestra em Letras e Doutora em Educação pela UFRGS. Professora colaboradora convidada do PPGEducação da Universidade Federal do Rio Grande do Sul.
} 


\section{PALAVRAS INICIAIS}

Exilados, migrantes, refugiados, desterrados, expatriados, diaspóricos - várias são as formas com que os sujeitos que deixam sua terra natal (por distintos motivos e em diversas condições), atravessam fronteiras e se deslocam para outros países são nomeados. Burke (2017), em seu estudo sobre os "exilados e expatriados na história do conhecimento na Europa e nas Américas, 1500-2000", explora um “vocabulário do exílio", rastreando o surgimento e o peso semântico atribuído pela história a alguns desses termos. Mas, se o estudo de Burke - e o próprio autor o admite centra-se sobretudo nos "ganhos" de conhecimentos e saberes (e o título do livro é "Perdas e ganhos") que os exilados trouxeram aos lugares e situações que os acolheram, a midiatização mais recente das fugas de milhares de refugiados de seus lugares de origem, em função de catástrofes naturais, guerras, conflitos, privações econômicas, perseguição política, religiosa, étnica, tem fixado na retina dos não migrantes sobretudo uma imagem de sofrimento, riscos, desamparo e situações limite de desespero.

Abandonar o país de origem é, por vezes, a alternativa que resta a milhões de pessoas submetidas a governos autoritários, a índices insuportáveis de violência ou a condições que já não desejam para seu futuro, afirma Canclini (2016). O ato de migrar, que implica abrupta ruptura com um território no qual se consolidam sentidos de pertença, pode envolver simultaneamente sentimentos de amargura e temor, mas também de esperança e crença no futuro. Conforme o autor, estatísticas oficiais mostram que 57,5 milhões de pessoas da América Latina e do Caribe vivem fora de seus países (42,8 nos Estados Unidos), mas estima-se haver número muito superior, já que muitos migrantes vivem em condição de clandestinidade. Alguns países como Equador, México e Uruguai perderam, ainda conforme o autor, $10 \%$ a $15 \%$ de sua população nos movimentos migratórios dos últimos anos.

Cogo (2007), por sua vez, afirma que cerca de $2,8 \%$ da população mundial é constituída por migrantes e todos os continentes são, na atualidade, polos de deslocamento, trânsito e acolhida de migrações contemporâneas. Tais movimentos migratórios são dinâmicos e múltiplos, e poderiam ser exemplificados, conforme a autora, no fluxo de imigrantes turcos para a Alemanha, no período pós-guerra; no exílio de espanhóis em decorrência da pobreza e de episódios como a Guerra Civil e a ditadura franquista (e posterior abertura, da Espanha, para receber imigrantes); no crescimento dos fluxos migratórios provenientes do continente europeu e americano para países como Brasil e Argentina etc.

Nestes fluxos, pessoas cruzam fronteiras e, com elas, também são postos em trânsito recursos econômicos, informações, tecnologias, histórias, gostos musicais, bens, signos, formas de vida. Conforme salienta Canclini (2016, p. 60), "as remessas de ida e volta fazem ver que o desterro não é só intempérie; negocia-se entre o que se abandona e o que se adquire e compartilha". Na crescente e às vezes perturbadora presença de migrantes, forjam-se outros sentidos para o "habitar", o que permite entender, ademais, que as categorias espaço-temporais não são fixas e que as identidades não estão, de todo, estabilizadas.

Vê-se, assim, que os movimentos migratórios não são novidade na história humana e raros serão os leitores deste artigo que não saibam referir a existência de algum antepassado (de poucas gerações) que migrou para o Brasil, de forma mais ou menos voluntária, ou, então, que foi trazido, na condição de "escravizado". Como fenômeno humano, as migrações variaram (e variam) de volume, origem, destino, motivações, condições, formas e, na medida em que a literatura é uma arte fundada na experiência humana recriada pela palavra, já de partida poderia se supor que tratasse dessa temática.

Já se tomarmos como foco a literatura para crianças e jovens e, simultaneamente, as características mais candentes das atuais migrações - em especial, as que dizem respeito aos dramas dos refugiados - podemos supor uma menor frequência desta temática. Temas considerados difíceis (ou "delicados", ou "polêmicos", em outras nomeações) têm uma presença rarefeita nos livros para crianças, tanto em função da imagem do interlocutor - eventualmente visto como inocente, imaturo e, portanto, alguém a ser protegido de eventuais desconfortos que tais temáticas poderiam produzir - quanto em virtude do temor da censura de pais, grupos religiosos, gestores e, em decorrência, pelo receio de prejuízos comerciais numa eventual edição. Sob outro ponto de vista, percebe-se que a abordagem de tais temas em livros para crianças é frequentemente perpassada por um intuito pedagógico explícito - de ensinar sobre os fenômenos e formar 
no pequeno leitor atitudes desejáveis - que mina seu caráter estético e os torna, não raramente, algo como aulas ilustradas.

Pois bem: é no encontro entre estes dois campos de estudo - o das migrações humanas e o da literatura para crianças e jovens - que se situa o presente estudo. Assim, levando em conta a universalidade dos movimentos migratórios na história do mundo e a concepção de literatura (incluindo aquela dirigida para crianças e jovens) como transfiguração estética das vivências, sentimentos, problemas e dilemas das pessoas, nosso objetivo é explorar, neste artigo, a articulação entre migração e literatura.

Para a exploração desta articulação - entre migração e literatura para crianças e jovens - realizaremos, neste artigo, dois movimentos analíticos principais: o primeiro, voltado para a apresentação e breve análise de 7 títulos, publicados a partir de 2011 e disponíveis para crianças e jovens leitores brasileiros, os quais têm como temática central a migração; o segundo, dedicado ao relato de uma sessão de leitura compartilhada envolvendo um dos livros apresentados e realizada com uma turma de alunos do $5^{\circ}$ ano do ensino fundamental, em uma escola pública de Porto Alegre. Para tal análise, foram consideradas as negociações feitas entre as experiências pessoais dos alunos e o texto e as imagens do livro discutido, assim como as produções (de textos e desenhos) dos alunos, após a leitura ${ }^{2}$.

De certa forma, nosso intento maior é mostrar, por um lado, a presença sensível de uma temática onipresente dos grupos humanos - e que vem se agudizando e adquirindo inédita visibilidade com as inúmeras questões de refugiados - nas obras literárias para jovens leitores e, por outro lado, chamar atenção para a produtividade possível de sua leitura e discussão por leitores que, à primeira vista, poderiam ser considerados distantes da problemática.

\footnotetext{
${ }^{2}$ A sessão de leitura compartilhada aconteceu dentro do projeto já mencionado - "Percursos e representações da infância em livros para crianças - estudo de obras e leituras" - que foi submetido e aprovado no Comitê de Ética em Pesquisa da Universidade Federal do Rio Grande do Sul, tendo seguido todos os trâmites referentes à obtenção de Termos de Consentimento e Termos de Assentimento das crianças e seus responsáveis. Por questões de sigilo, não há identificação nem de escola nem de alunos.
}

\section{LITERATURA INFANTOJUVENIL E MIGRAÇÃO}

Nas duas últimas décadas, a Europa ocidental - que em vários outros momentos históricos foi ponto de partida de migrantes - tem recebido fluxo considerável de migrações, principalmente da Ásia, da África, da Europa oriental e da América Latina; não por acaso tem havido um esforço de certos setores da sociedade organizada em incorporá-los a suas comunidades. Tal é o caso, conforme nos aponta a obra "La literatura que acoge: inmigración y lectura de albúmenes" (COLOMER; FITTIPALDI, 2012), organizada pelo Grupo GRETEL, da Universidad Autónoma de Barcelona (UAB), de várias pesquisas que se debruçam sobre os vínculos possíveis entre as crianças e jovens que chegam às novas pátrias e a leitura de livros literários. À parte a alentada pesquisa levada a cabo pelo grupo e que é objeto dos estudos da obra citada, interessa-nos aqui a referência a uma análise preliminar de 50 livros infantis e juvenis publicados na Espanha, durante a primeira década do século XXI sobre o tema "imigração".

Algumas tendências detectadas no conjunto de obras levantadas pela equipe catalã foram: a predominância da perspectiva do migrante que chega ou já vive nas novas sociedades; o predomínio da narrativa em $1^{\text {a }}$ pessoa ou em $3^{\text {a }}$ pessoa focalizada nos protagonistas, como recurso de proximidade; a descrição de um catálogo de males como causa da migração (guerra, secas, greves); a predileção por lugares de partida mais exóticos e uma descrição sobretudo sensorial do tipo de vida próprio do mundo abandonado. Tais tendências se integravam a uma dimensão maior de uma atitude positiva (esperada) em relação à convivência e integração, uma descrição sem muita complexidade do tema migratório e "uma mirada propia de las sociedades occidentales de acogida que proyectaba una visión tópica hacia los lugares de procedencia." (COLOMER; FITTIPALDI, 2012, p. 20)

Ao nos voltarmos para o panorama dos livros disponíveis para crianças e adolescentes brasileiros, a pujança de títulos sobre migrações é bem mais modesta e se constitui quase exclusivamente por traduções. Em uma busca por catálogos, listas de revistas especializadas e sites também especializados, localizamos sete títulos recentes sobre o tema, publicados desde 2011, em obras escritas por autores de diferentes 
nacionalidades (Austrália, Inglaterra, Itália, Colômbia, México, Argentina), ressaltando-se a presença de autores e ilustradores latino-americanos - colombianos, cubanos, mexicanos e argentinos. Cinco casas editoras abrigaram tais títulos, dos quais faremos uma breve descrição a seguir, para, depois, buscar seus pontos comuns e divergentes.

Destaca-se, neste conjunto, não apenas pelo seu tamanho, mas também pela sua inegável qualidade estética e simbólica, a obra A chegada (The Arrival, no original), do australiano Shaun Tan, publicada no Brasil por Edições SM, em 2011. Trata-se de um livro com uma narrativa apenas de imagens que, pela sua extensão e complexidade de referências, não tem como destinatário o leitor infantil, mas o jovem e o adulto. Entretanto, tendo sido uma das obras discutidas com alunos migrantes da pesquisa realizada pelo GRETEL, da UAB, detalhadamente descrita em Colomer e Fittipaldi (2012), nos relatos da pesquisa encontramos interpretações de alunos adolescentes, de 12 a 14 anos.

A chegada consiste em uma narrativa longa, constituída por 790 imagens de variados tamanhos, enfeixadas em um volume que já simula um livro envelhecido, pela capa, integrando o projeto gráfico primoroso da obra. Tendo recebido vários prêmios, foi fruto - conforme o próprio autor declara - de um trabalho de quatro anos de pesquisas, das quais foram aproveitadas referências visuais diversificadas, incluindo registros em jornal, filmes de época e fotografias de migrantes disponíveis em acervos museológicos, tal como informa um dos paratextos incluídos nas páginas finais do livro. Nas palavras do próprio autor, no texto da contracapa, "Esses quadrinhos sem palavras contam a história de cada refugiado, cada migrante, cada deslocado à força, em diferentes países e períodos históricos, homenageando todos aqueles que tiveram de fazer uma viagem desse tipo" (TAN, 2011). Como exemplo desta busca de generalização - também presente no recurso de encaixe de histórias de outros migrantes, para além da do protagonista -, vemos que as capas internas da obra são compostas de um painel com 60 rostos diferentes, como fotos $3 \times 4$, de modo a exibir um grande conjunto de migrantes, bastante diversificado em termos de etnias, gêneros, idades, penteados, adereços de cabeça etc.

Também um livro apenas de imagens, Migrando é de autoria da artista plástica argentina Mariana
Chiesa Mateos, com duas narrativas impressas em sentidos e direções opostas (o livro pode ser aberto e lido de frente para trás ou de trás para frente). A obra recebeu apoio da Anistia Internacional e foi publicada, no Brasil, pela Editora 34, no ano de 2015. Um paratexto de apresentação explica que a autora pretendeu criar "uma obra poética aberta a múltiplas interpretações e que, assim como o próprio fenômeno da migração, propõe ao leitor a experiência de vários pontos de vista ao mesmo tempo" (MATEOS, 2015, $\mathrm{s} / \mathrm{p})$.

Já o livro Um outro país para Azzi apresenta uma história em quadrinhos escrita e ilustrada pela inglesa Sarah Garland, com tradução de Érico Assis e edição da Editora Pulo do Gato, em 2012. A guerra é o ponto de partida da narrativa e, neste contexto, a protagonista é forçada a fugir, com seus pais, para outro espaço para viver. A história focaliza, de modo especial, os processos de adaptação da pequena menina, que passa a viver como refugiada e encontra na escola um espaço de acolhimento e de retomada do curso de sua vida.

A obra $A$ viagem, escrita e ilustrada pela italiana Francesca Sanna, foi publicada por Vergara \& Riba Editoras, em 2016, e traduzida para a língua portuguesa por Fabrício Valério. A autora explica, em um paratexto da obra, que conheceu duas meninas em um centro de refugiados na Itália e, entendendo que suas histórias carregavam sentidos muito poderosos, decidiu criar uma obra literária na qual pudessem ser apresentadas imagens de vidas de migrantes e de refugiados. A história, contada sob a perspectiva de um narrador criança, situa-se no contexto de migração de uma família constituída pela mãe e dois filhos pequenos.

As obras Eloísa es bichos e Para onde vamos foram escritas pelo colombiano Jairo Buitrago, ilustradas pelo cubano Rafael Yockteng e traduzidas para o português por Márcia Leite. Ambas foram publicadas pela Editora Pulo do Gato, a primeira em 2013, e a segunda em 2016. As histórias também se constroem desde a perspectiva de narradores crianças - Eloísa, personagem central da obra Eloísa e os Bichos é uma menina que chega, ainda pequena, a uma nova cidade e, neste ambiente, precisa aprender outra língua e deve se adaptar a rotinas escolares e a circunstâncias culturais pouco familiares. De modo semelhante, a protagonista-narradora de Para onde vamos é uma 
pequena menina que viaja com o pai, compartilhando o caminho com dezenas de pessoas que migram e buscam refúgio em outros países.

Migrar é uma obra escrita pelo mexicano José Manuel Mateo e ilustrada pelo também mexicano Javier Martínez Pedro. Foi traduzida para o português por Rafaella Lemos e publicada pela Editora Pallas, em 2013. A obra é ilustrada em papel amate, com técnica empregada pelo povo Xalitla, do México, para contar histórias míticas e tradicionais. O tipo de encadernação possibilita que as páginas sejam abertas uma a uma, ou desdobradas e expandidas de modo a formar um grande e único painel. As ilustrações são densas, ricas em detalhes, e constroem sucessões de cenas que, no todo, narram ações descritas no texto verbal (por um narrador criança), vinculadas ao processo de migração de uma família constituída pela mãe e dois filhos pequenos (um menino e uma menina).

\section{MOTIVAÇÕES, PERCURSOS E PONTOS DE CHEGADA: ALGUNS PONTOS DE ARTICULAÇÃO ENTRE AS NARRATIVAS LITERÁRIAS}

Nesta seção, focalizaremos recorrências encontradas nas sete obras selecionadas para este estudo, considerando, de modo especial, a situação inicial das narrativas, os percursos de migração das personagens - nos quais se expõem dificuldades, perigos, mas também laços sociais que se constituem no caminho - e os pontos de chegada deles ao final destas histórias ${ }^{3}$.

Em relação à situação inicial das narrativas, de modo geral se apresenta um contexto harmônico que é rompido por conflito ou guerra. A obra Migrar, narrada em primeira pessoa, focaliza um quadro de lembranças da personagem criança e, na cena inicial, os verbos são conjugados no passado, denotando acontecimentos habituais anteriores a alguma mudança abrupta: "Eu brincava de correr entre galos e porcos. Os animais andavam soltos, porque na roça não havia currais ou cercas entre as casas [...]. Meu pai plantava melancias e arvorezinhas de mamão. $\mathrm{O}$ terreno era grande, mas não pertencia ao meu pai" (MATEO, 2013. s/p). Uma situação conflitiva é então inserida - nos textos verbais e imagéticos - para

\footnotetext{
${ }^{3}$ Como apresentaremos, adiante, uma análise de uma sessão de leitura e discussão com a obra $A$ viagem, para evitar repetições optamos por fazer aqui apenas breves referências a esta narrativa.
}

justificar a necessidade de migração, e o estopim da mudança parece ser um conflito fundiário:

Mas as coisas mudaram de repente! Os vizinhos
pararam de plantar. Primeiro Seu Augusto se foi. Em
um ano voltou e levou seus filhos homens. O mesmo
fizeram os demais adultos. Por fim, meu pai também
se foi e na cidade sobraram apenas as mulheres e
algumas crianças. Minha mãe quis plantar no terre-
no, mas o dono não deixou... Assim, um dia, minha
mãe juntou suas coisas numa bolsa, nos pegou pela
mão e deixamos nossa casa (MATEO, 2013. s/p).

Um outro país para Azzi, história em quadrinhos, é apresentada do ponto de vista de um narrador onisciente e inicia do seguinte modo: "Havia um país em guerra e é lá que começa essa história. A história de Azzi." (GARLAND, 2012, p.3). As atribuições familiares são apresentadas - o pai da personagem era médico, a mãe costurava roupas e a avó tecia cobertores, Azzi ia ao colégio e brincava com amigos depois das aulas - para constituir um sentido de cotidianidade e estabilidade, que é rompido com a afirmação de que "a cada dia a guerra se aproximava mais e mais da casa de Azzi”" (GARLAND, 2012, p. 4). O personagem pai recebe um telefonema misterioso e a família é forçada a fugir, às pressas, deixando para trás seus pertences, a casa, o mundo conhecido e a avó da personagem menina, que somente no final da narrativa une-se novamente à família.

O livro de imagem Migrando é produzido de modo a permitir que o leitor acesse a narrativa por dois pontos de partida: de frente para trás, o leitor é contextualizado em uma cena de despedida entre duas personagens femininas; de trás para frente, imagens de aves sobrevoando bagagens dispostas no chão fazem pensar em migrações em massa. Desse modo, entende-se que as personagens estão em movimento e, pela presença abundante de aves, vincula-se tal ação ao sentido de movimento migratório.

Já na obra $A$ chegada, pequenos objetos - um retrato de família e um desenho de criança - são cuidadosamente embalados e dispostos junto às roupas $\mathrm{e}$ objetos pessoais na bagagem do personagem pai, que se prepara para uma viagem. As imagens da partida, as metáforas visuais inseridas na paisagem urbana noturna, o semblante entristecido das personagens, as precárias condições enfrentadas no percurso, entre outros aspectos, apontam para uma interpretação de que se trata de uma migração por razões graves, mas, 
ao final da narrativa, a personagem consegue inserir-se no mundo produtivo em um novo país e pode, assim, custear a vinda de sua família.

Diferente das obras anteriores, Para onde vamos já inicia com suas personagens no movimento de migração. A afirmação "Quando viajamos, eu vou contando tudo o que vejo" (BUITRAGO, 2016, s/p) abre a narrativa e é complementada por uma sequência de imagens que permitem ao leitor entender que se trata de um viajar clandestino, marcado pela precariedade das formas de se locomover - em balsas de carga, na parte externa de vagões de um trem, por exemplo - e pela presença de outros tantos migrantes, que também viajam em condições semelhantes.

Também a obra Eloísa e os bichos tem como ponto de partida a situação de adaptação a um novo país. A afirmação "Eu não sou daqui" estabelece a condição de estrangeira para a protagonista narradora, que explica: "Chegamos numa tarde, quando eu era bem pequena. Enquanto papai procurava trabalho eu ia para a escola... E me sentia um bicho estranho" (BUITRAGO, 2013, p 4-11). O sentimento de estranheza diante do novo contexto é figurativamente apresentado, sendo os habitantes deste novo lugar com os quais a pequena menina precisa conviver, representados sob a forma de insetos. Ao final, quando os sentimentos de solidão e de desconforto da personagem são dissipados, é ela que surge, na forma de um inseto, junto da professora e de seus colegas sorridentes.

Em relação aos percursos de migração, as obras apresentam vários pontos em comum, em especial concernentes às dificuldades e perigos enfrentados no caminho. Há um esforço em representar sentimentos experimentados pelas personagens, assim como em inserir signos que indiquem o cruzamento de fronteiras nacionais. De modo geral, a viagem destas personagens inicia-se à noite, clandestinamente, e aponta-se a precariedade nas condições de travessia de florestas, desertos, rios e oceanos.

Assim, os textos verbais e imagéticos de Para onde vamos e $A$ chegada focalizam o cruzamento da fronteira, as dificuldades e o recurso a meios clandestinos, tais como o pagamento aos "coiotes" (termo usualmente empregado para denominar aqueles que realizam, através de cobrança, travessias clandestinas de pessoas de um lado para outro de uma fronteira). A figura de um animal (o coiote) é inserida na obra Para onde vamos, junto a uma placa indicativa de área de fronteira, e volta nas ilustrações subsequentes, mantendo-se como elemento metafórico presente em quase todas as imagens. Sutilmente são referidas, na obra, as precárias formas de acomodação, de travessia e de trabalho oferecidas a quem está migrando ou se refugia em um outro país. Em um paratexto (ao final da narrativa principal) explica-se: "Sabemos que, a cada ano, milhões de pessoas em todo o mundo se transformam em refugiados [...]. Pra isso, precisam pagar a pessoas conhecidas como 'coiotes', que a princípio seriam responsáveis por ajudá-los na longa e arriscada travessia, mas que muitas vezes apenas tomam seu dinheiro e os abandonam." (BUITRAGO, 2016, s/p).

A presença de guardas de fronteira também é mencionada no texto de $A$ chegada: "Algumas noites, quando não consigo dormir, começo a contar estrelas. São milhares de estrelas, assim como as pessoas. E conto a lua, que está sempre sozinha. Às vezes, também vejo soldados, mas esses eu já nem conto. Acho que são mais de cem." (BUITRAGO, 2016, $\mathrm{s} / \mathrm{p})$. A imagem, em segundo plano, exibe silhuetas de soldados, fortemente armados, de costas para a cena principal, resguardando o território situado no outro lado de um sólido muro.

Na maioria das obras selecionadas, é recorrente a representação de meios de transporte utilizados ao longo dos percursos migratórios. Exemplo disso são os percursos terrestres, realizados pelas personagens em meio a caixas de alimentos e animais e, ainda, os trajetos clandestinos, no lado exterior de vagões de trens (Para onde vamos, Migrar, A viagem). Já em percursos marítimos, os pequenos barcos cargueiros ou botes frágeis e abarrotados de pessoas são apresentados nas obras Para onde vamos, A viagem, Migrando, Outro país para Azzi. A precariedade das embarcações e os perigos da travessia são marcados, algumas vezes, com ilustrações metafóricas, alusivas a gigantescos animais marinhos (por exemplo em $A$ viagem), ou pela marcação da pequenez da personagem frente a ondas do mar ou nuvens carregadas, no céu (como em $A$ Chegada). Também é recorrente a presença de um grande número de outros imigrantes reunidos em acampamentos provisórios, escondendo-se, sendo perseguidos por policiais, saltando cercas de arame farpado, ou seja, vivendo situações de perigo e precariedade semelhantes às dos protagonistas da narrativa, tal como ocorre nas obras Migrando, Para 
onde vamos, Migrar, A chegada, A Viagem, Outro país para Azzi.

Medo, angústia, incerteza e saudade são sentimentos evocados, nos textos por afirmações como "[...] eu ia para a escola/ e me sentia um bicho estranho" (BUITRAGO, 2013, p. 9 e 11); “Os recreios eram muito longos/ tão demorados quanto ficar esperando o papai chegar, na saída" (BUITRAGO, 2013, p. 17 e 19); "E que saudade de casa" (MATEO, 2013, $\mathrm{s} / \mathrm{p})$.

Nas ilustrações, também se estampam sentimentos experimentados pelas personagens - tanto infantis, quanto adultas. Na obra $A$ chegada, por exemplo, pode-se entender que o personagem pai está sozinho, olhando para um porta-retratos com a imagem da família deixada no país de origem. Em um momento da narrativa - feita apenas de imagens sequenciais e sem texto verbal - a cena, em plano fechado, aos poucos situa a personagem em um pequeno aposento, visto por uma janela circular, que se distancia mais e mais, até que seja possível vislumbrar um imenso navio. A imagem seguinte ocupa duas páginas e mostra o navio (em tamanho reduzido) sob um amplo céu coberto de nuvens densas e ameaçadoras. Os recursos de envelhecimento das imagens intensificam o sentido de desalento que, sob a perspectiva da personagem, esse contexto produz.

Já na obra Migrando, sentimentos de saudade e solidão parecem representados na imagem de uma jovem que deixa a mãe e sobrevoa a paisagem sobre os ombros de um grande pássaro branco, quando o livro é folheado em uma das direções possíveis. Já na direção contrária, as ilustrações possibilitam pensar nos riscos enfrentados por migrantes, em cenas nas quais as aves migratórias (com semblantes humanos) são alvejadas por caçadores. O sentido de vulnerabilidade destas vidas migrantes que atravessam clandestinamente as fronteiras é, desse modo, construído, e o desfecho das histórias não as posiciona em um lugar seguro, e sim as mantêm em fluxo - elas não chegam ao destino definitivo e se mantêm em viagem.

Tal aspecto remete a dois principais tipos de desfecho das narrativas selecionadas. O primeiro tem, como situação final, a fixação das personagens em um novo país, e o segundo tem na viagem que prossegue e que não tem ponto de chegada a sua finalização neste caso, as personagens não encontraram, ainda, seu "porto seguro", mas as narrativas produzem um ponto de ancoragem - a esperança de encontrar um bom lugar para viver, a alegria de ter deixado para trás um contexto de perigo, pequenos afetos por pessoas ou animais encontrados no caminho.

Nas obras em que as personagens se instalam e reconstroem a vida em um novo lugar - Um outro país para Azzi, A chegada, Migrar e Eloísa e os Bichos - há, em comum, a construção de certo sentido de segurança e acolhimento, embora em condições econômicas mais precárias, para as personagens, do que aquelas deixadas em seus lugares de origem. Nessa direção, em Eloísa e os bichos apresenta-se a busca de trabalho empreendida pelo personagem pai, assim como as longas travessias de metrô, da escola até a casa.

No livro Migrar, o narrador informa: "Na casa onde estamos agora mora muita gente, algumas pessoas são até de outros países [...] mas devem ser de cidadezinhas como a nossa, porque todos somos parecidos. O bom de ter vindo é que nos deram trabalho: vamos começar limpando casas. Bom, não posso escrever mais porque vão apagar a luz" (MATEO, 2013, s/p). Casas de acolhimento ou habitações clandestinas que reúnem grande número de pessoas são aqui representadas, e a menção a ter que apagar a luz parece indicar que a personagem criança ocupa um cômodo coletivo, o que pode apontar para a precariedade econômica. Também na obra Um outro país para Azzi, esse aspecto é salientado quando a "nova casa" em que a família foi morar é assim descrita: "Era pequena, com um só aposento, um banheiro e uma varanda. 'Olhe Azzi', disse mamãe. 'Pessoas muito gentis nos deram móveis e uma panela'. 'Em breve terei o visto de trabalho', disse papai. 'Aí teremos uma casa melhor'”. (GARLAND, 2012, p. 13).

As narrativas em que as personagens encontram um novo país para viver, também investem na alusão a barreiras linguísticas e a dificuldades enfrentadas inicialmente, tanto em obter trabalho com remunerações mais condizentes com suas necessidades, quanto em lograr êxito nas interações sociais, ao menos em um primeiro momento. Contudo, as personagens crianças apresentam destrezas especiais no que concerne à socialização e comunicação em contextos interculturais e plurilíngues. A amizade entre a personagem menina e um personagem menino, na obra Para onde vamos, exemplifica tal aspecto, assim como os vínculos 
estabelecidos no espaço escolar pelas personagens Eloísa (Eloísa e os bichos) e Azzi (Outro país para Azzi).

Por outro lado, nas obras em que as personagens não chegam a um destino final e são mantidas em fluxo migratório (Para onde vamos, A viagem e Migrando), parece haver um esforço de inserção de certos ícones, capazes de mobilizar um sentimento de solidariedade no leitor e também de marcar as pequenas alegrias vivenciadas ou situações de momentâneo alento experimentadas no caminho. Na obra Para onde vamos, a narrativa se encerra com a declaração "E voltamos a viajar", seguida da adversativa "Mas agora eu tenho dois coelhos brancos", a qual traz uma informação que se contrapõe à direção mais pessimista da afirmação anterior. A ilustração, por sua vez, mostra dois pequenos animais brancos correndo livres em um gramado, cujo limite é um extenso muro de uma fronteira.

A obra Migrando, por sua vez, abre-se para diferentes interpretações sobre os caminhos trilhados por sujeitos em migração precária (apresentados na forma de aves migratórias) e sujeitos que viajam e adotam outros mundos como lugares de morada. Pode-se imaginar que o ato de migrar reúne pessoas provenientes de distintos lugares em torno de desejos comuns e de expectativas de recomeço. Os sentidos de esperança e de busca por condições mais adequadas de vida são mobilizados, por exemplo, por meio de metáforas como a das aves migratórias ( $A$ Chegada, $A$ viagem, Migrando), que ignoram fronteiras humanas e podem funcionar como ícones de liberdade.

Antes de finalizar esta seção, é relevante indicar que as sete obras apresentam paratextos que situam o tema e o contextualizam no panorama dos movimentos migratórios mundiais da atualidade. Argumentos sobre o ato de migrar e seus desafios são inseridos, a exemplo do que segue - "Mudar de país, mudar de paisagem. Deixar para trás a língua conhecida, os rostos familiares, e se abrir para novas caras e novos sons. Este é o desafio de quem migra" (MATEOS, 2015, s/p).

Assim, alguns paratextos das obras Migrando, Para onde vamos, Migrar e Outro país para Azzi fazem referência a milhões de pessoas que se veem obrigadas a abandonar a vida que conhecem e a partir em busca de adequadas condições de segurança, saúde ou, ainda, de novas oportunidades de trabalho. Na obra
Migrar, por exemplo, um paratexto situa a viagem em um contexto específico: "Milhares de meninas e meninos migram para os Estados Unidos todos os anos (fala-se em 50 mil) mas nem todos fazem o percurso com seus familiares [...]. Se lançam a uma viagem cheia de perigos porque têm a esperança de encontrar trabalho, de viver em paz ou porque desejam, justamente, reunir-se à sua família" (MATEO, 2013, s/p). $\mathrm{O}$ texto prossegue informando que muitos desses meninos e meninas são explorados, abusados, vendidos, assassinados, desaparecem no caminho, tornam-se invisíveis. "Escrevemos este livro para não esquecer que as meninas e meninos migrantes existem e sofrem [...] e também porque outra realidade reclama ativamente seu direito de existir" (MATEO, 2013, s/p). Em um paratexto do livro Para onde vamos, destaca-se que grande número de crianças é forçado a migrar junto a seus pais, seja pela falta de condições econômicas de permanecer em seus países, seja por conflitos e guerras. Desse modo, os paratextos também funcionam como pontos de ancoragem para um leitor que desconhece o contexto narrado, bem como a multiplicidade dos processos migratórios que marcam a atualidade.

\section{LEITURA E DISCUSSÃO DA OBRA A VIAGEM: IMPRESSÕES E NEGOCIAÇÕES DE LEITORES- CRIANÇAS FRENTE AO TEMA DAS MIGRAÇÕES}

O trabalho descrito a seguir é um recorte de projeto de pesquisa, do qual participam as autoras deste artigo, cujo objetivo geral é analisar gestos de compreensão leitora de alunos dos anos iniciais de escolas públicas, frente a um conjunto delimitado de obras literárias consideradas desafiadoras. Além de trabalhos analíticos sobre um acervo de livros infantis de publicação recente que trouxessem personagens crianças, a metodologia do projeto previa a realização de oito sessões de leitura compartilhada em sala de aula, com livros diversos previamente escolhidos pela equipe de investigação, em turmas de $4^{\circ}$ ou $5^{\circ}$ ano (9 a 12 anos) de duas escolas da rede pública. Cada dupla de crianças recebia um exemplar da obra trabalhada e, após a leitura compartilhada, procedia-se a uma conversa sobre a leitura, inspirada em autores como Chambers (2007), que enfatizam a relevância de uma conversa não diretiva sobre as obras, e a alguns 
trabalhos variados (textos, desenhos), cujo principal enfoque era a possibilidade de articulação de aspectos do livro à experiência pessoal de cada criança.

Em uma das sessões de leitura compartilhada, realizada com uma turma de $5^{\circ}$ ano de uma escola municipal de Porto Alegre (localizada em bairro de reconhecida vulnerabilidade social), foi lida e discutida a obra $A$ Viagem, de Francesca Sanna, um dos livros referidos na seção anterior. A partir da análise de algumas passagens da discussão sobre o livro e de alguns trabalhos posteriormente realizados, procuraremos trazer marcas das leituras que o contato com a obra e sua discussão proporcionaram aos pequenos alunos.

Como foi anteriormente referido, a obra $A$ viagem, ao abordar o drama humano da migração, retrata a fuga de uma família de sua terra natal, devido à guerra, numa jornada repleta de perigos, anseios, angústias e medo, que nos é contada pelos olhos de uma criança, personagem e narradora da história. Inicialmente, delineia-se um breve panorama de lembranças da narradora, mostrando a situação anterior a uma repentina mudança - "Eu vivia com minha família em uma cidade perto do mar" (SANNA, 2016, s/p). Então, um contexto de guerra é anunciado: "Durante o verão, costumávamos ir à praia. Mas nunca mais fomos lá, pois, no ano passado, nossas vidas mudaram para sempre... A guerra começou. Todos os dias, coisas ruins aconteciam à nossa volta e, em pouco tempo, não havia mais nada além do caos" (SANNA, 2016, s/p). Nas imagens, uma grande mancha preta estende-se sobre a praia e destrói casas, personificando a guerra e as catástrofes dela derivadas.

O temor ao desconhecido e, ao mesmo tempo, a coragem de buscar refúgio se apresentam, por exemplo, quando a personagem mãe mostra às crianças "imagens de cidades estranhas", "florestas estranhas, animais estranhos", enquanto diz aos filhos "Vamos para lá e nunca mais voltaremos a sentir medo" (SANNA, 2016, s/p). Na ilustração, as personagens humanas aparecem em tamanho reduzido e estão rodeadas de animais como ursos, alces, veados, corujas e lobos em tamanho ampliado, o que alarga o sentido de fragilidade e insegurança de quem se prepara para migrar. A viagem é iniciada no meio da noite, às escondidas, no carro da mãe, e uma sequência de imagens mostra a família alternando veículos, camuflando-se entre cargas de alimentos, por exemplo. Malas e pertences vão sendo deixados ao longo do caminho, que vai se tornando sombrio e escuro e, na penumbra, as personagens migrantes vão se aproximando de um muro de fronteira. Figuras de guardas armados são mostradas em grande plano, como materialização do sentimento de medo que causam. Observa-se também a presença sutil, escondida entre árvores, de um coiote (neste caso, um animal, que metonimicamente aponta para os "coiotes" humanos que realizam travessias clandestinas entre fronteiras).

A narrativa se encerra com a imagem de aves migratórias, de diferentes formas e tamanhos, e, no dorso de uma delas, seguem sorridentes a mãe e os dois filhos, enquanto lê-se, no texto: "Do trem, eu via os pássaros que pareciam nos seguir... Eram migrantes como nós. E a viagem deles era tão longa quanto a nossa. Só que os pássaros podiam cruzar qualquer fronteira. Espero, um dia, como estes pássaros, que consigamos encontrar um novo lar. Um lar onde possamos ficar seguros e recomeçar a nossa história" (SANNA, 2016, s/p).

A esperança - aludida no texto escrito - amplia sua significação por meio da imagem positiva e, de certa forma, promissora, apresentada ao final.

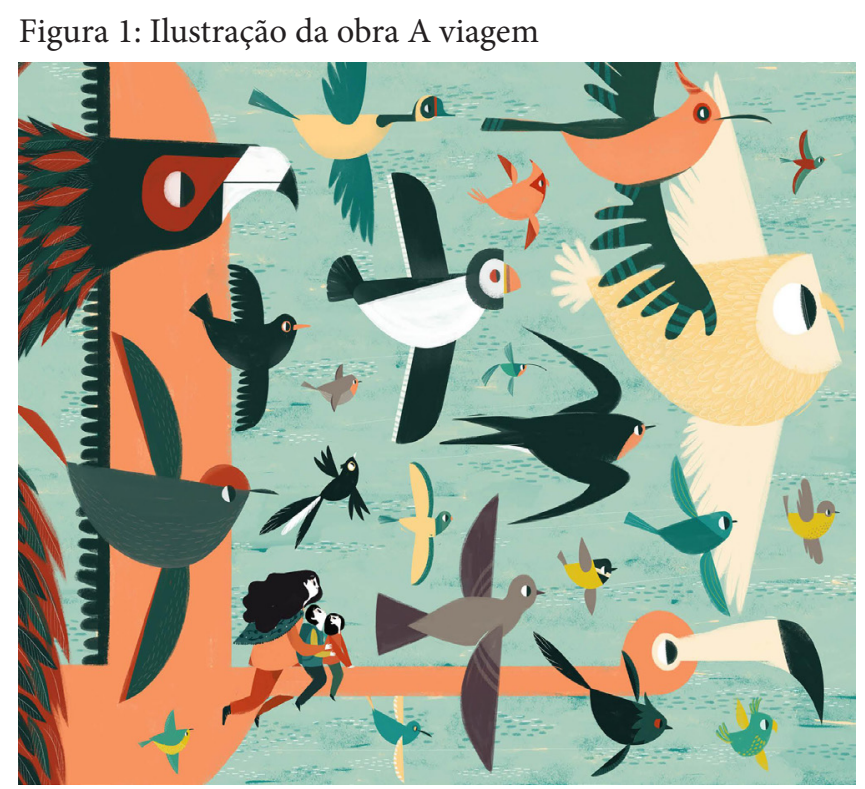

Fonte: SANNA (2016, p. 43)

Cademartori (2008, p. 87) dá relevo à relação entre texto e imagem em livros infantis, afirmando que, "além da beleza das imagens, da irresistível atração provocada pela variedade de cores e pelas aventuras das formas, a ilustração permite à criança $[. ..] \mathrm{o}$ 
acesso facilitado à história. Na representação, expõe aspectos do narrado que ajudam a esclarecê-lo". Ainda segundo a autora, a ilustração

[...] incita-lhe [a criança] a pensar analiticamente sobre o tema do livro e, sendo assim, exerce papel determinante na percepção e na produção de efeitos de sentidos implícitos, explícitos ou possíveis da literatura endereçada à criança. Possíveis, sim, porque as imagens, quando são ricas, deixam vazios e ambiguidades para o leitor resolver. (CADEMARTORI, 2008, p. 87).

Talvez seja esse o caso da imagem com a qual é finalizada a obra $A$ viagem (Fig. 1). Ela é polissêmica, ambivalente, permite variadas interpretações, aspecto que se expressa nas falas dos alunos, durante a leitura interativa da obra ${ }^{4}$ :

\section{$P 1^{5}::[\ldots .$.$] e aqueles pássaros têm alguma coisa a$ ver com essa história? \\ A4 $(o)^{6}$ : Sim, porque eles [as personagens] estavam tentando achar algum lugar... \\ A16(o): É que os pássaros que viajam de um lugar, vão pro outro... \\ A4(o): pro norte, pro sul, quando tá tendo inverno... \\ P 2: Aposto que vocês já viram vários pássaros voando... \\ A2(a): Pássaros voando em " $v$ "! \\ A9(o): Os pássaros vão pras árvores fazer ninho pros filhotinhos...}

Vale lembrar que, dentro da proposta mais geral do projeto, inspirada nos estudos de Chambers (2007) e em pesquisas anteriores da mesma equipe, as sessões de leitura se iniciavam com estratégias de predição de possibilidades de abordagens do livro a partir da capa e, após a leitura conjunta, em que cada dupla de alunos tinha acesso a um exemplar - como já mencionamos, ocorria uma sessão de conversa/discussão oral sobre vários aspectos da obra e percepções das crianças,

\footnotetext{
${ }^{4} \mathrm{~A}$ turma a que se referem os presentes dados era constituída por 29 alunos, mas nem sempre todos estavam presentes. As sessões - incluindo conversa inicial, leitura conjunta e discussão oral do texto - foram documentadas com gravação de vídeos e áudios. Além desse material, foram feitas anotações em diário de campo.

${ }^{5} \mathrm{P} 1$ e P2 - correspondem às vozes das pesquisadoras - pesquisadora $1 \mathrm{e}$ pesquisadora 2

${ }^{6} \mathrm{~A}$ letra A seguida de um número corresponde às vozes dos alunos. Números elevados não indicam maior quantidade de crianças, apenas a intervenção de um aluno cuja voz não é reconhecida, tal a superposição de vozes nos momentos de grande participação. As letras minúsculas (a) e (o) indicam o gênero das crianças, no caso, menina (a), menino (o).
}

mediada pela(s) pesquisadora(s) e professora. De tais discussões, é que foram retirados os excertos utilizados neste artigo.

Outras imagens que possibilitaram aos alunos uma interação fecunda entre o tema da obra e a criação de sentidos foram aquelas que representam a passagem pela fronteira. As ilustrações abaixo (Figuras 2 e 3) foram destacadas pelos alunos como imagens evocadoras de "raiva e perigo" 7

Figura 2: Passagem pela fronteira I

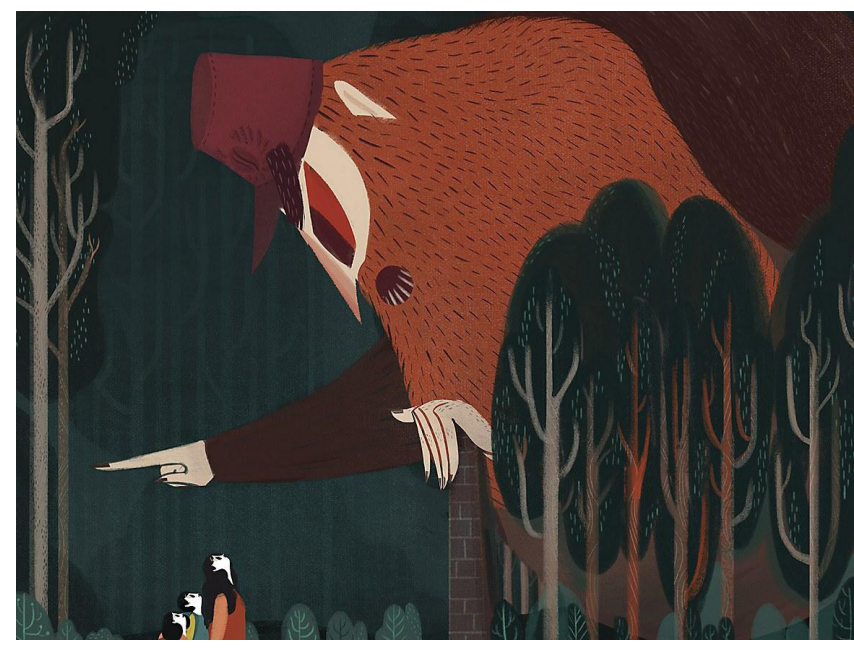

Fonte: SANNA (2016, p. 25)

Figura 3: Passagem pela fronteira II

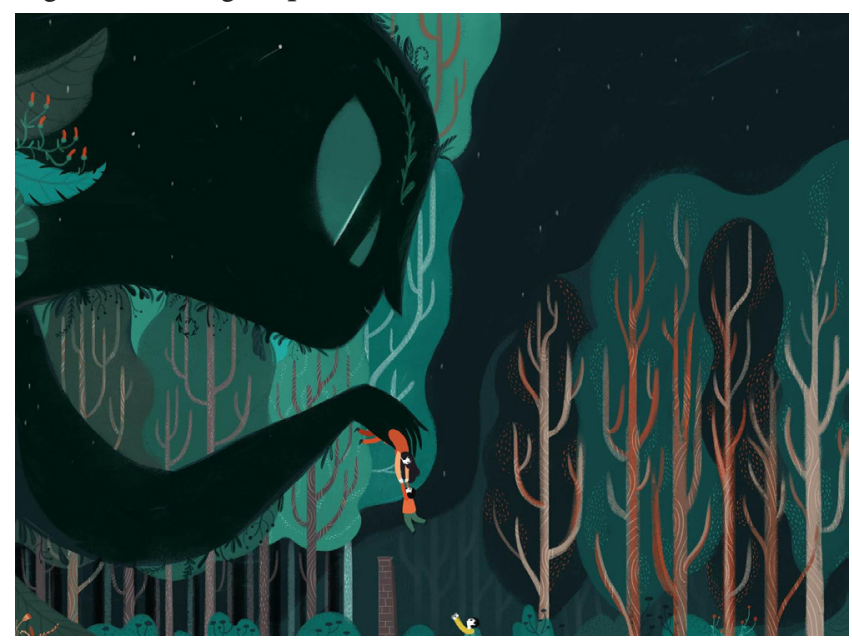

Fonte: SANNA (2016, p.31) 
As cores de fundo das figuras 2 e 3 trazem variações de verde musgo, com predominância de tons escuros, o que remete diretamente a cenas noturnas e a uma sensação de medo. Observa-se também o quanto as personagens principais ficam pequenas frente às personagens que simbolizam "guardiões" dessa fronteira, ou aos monstros imagéticos criados pela narradora. A autora lança mão de variados elementos imagéticos para caracterizar a dissimetria de poder existente na passagem pela fronteira, como o "guarda" gigante, barbudo, sisudo e autoritário ou, num plano mais fantasioso, a sombra de um monstro. Foram sugestões simbólicas percebidas por nossos leitores. Em conversas sobre essas páginas da obra, os alunos apontam essas questões. Inicialmente, eles destacam outras personagens da obra:

\section{P 1: Quem mais aparece na história?}

A34: O monstro de sombra...

A4(o): $O$ véio rabugento...

Posteriormente localizam essas personagens como algo que chamou atenção ou relacionando-as com pagamento de valores para "comprar" a permissão de passagem.

P 1: E aí, o que chamou a atenção de vocês nessa história?

A5(o): O gigante, porque ele ajudou eles a [inint]

A27(a): Por causa que a mãe dela deu dinheiro pra ele e ajudou...

Os leitores também chamaram a atenção para outros elementos relacionados à fronteira: a vigília constante, a observação, o "coiote". Os alunos apontam relações entre os olhos do "guarda da fronteira" e os olhos vigilantes que aparecem em outras páginas do livro.

P 1: Na próxima página?

A4(o): Uma raposa ali no cantinho!

P 1: Agora, página 24 e 25!

A46: A raposa tá de novo!

A26(a): Essa pessoa é o guarda...

A16(o): E o guarda parece que ele tem dente de tronco de árvore!

A5(o): Ele é um guarda gigante!

P 1: E será que ele é um gigantão? Por que será que ele aparece assim?

A47(o): Porque ele tá xingando eles...
A28(a): Tá se sentindo o maioral!

-..

Professora: Por que será que tinham tantos olhos?

A48: Era o monstro da guerra!

A2(a): A cor desses olhos é a mesma cor da do guarda...

$\cdots$

A9(o): Tem olhos aqui também.

A2(a): Tava observando eles...

É interessante destacar também como a criação de uma conversa, em que as "marcas de migração" foram sendo aos poucos contextualizadas, ampliou as possibilidades da compreensão leitora da obra. Deste modo, questionamentos como: E será que ele é um gigantão? Por que será que ele aparece assim? Por que será que tinham tantos olhos? podem ser entendidos como contextos de significação compartilhados, e que possibilitam que se constituam os discursos pedagógicos (SILVEIRA, 1995). Assim, a leitura e discussão cuidadosa da obra e de suas imagens complexificam a interação construída durante a leitura. Essa intrincada interação ocorre entre os leitores e a obra, provocada pela mediação da leitura por um terceiro: o professor ou o pesquisador. Nesse sentido, observar que a passagem pela fronteira tem algumas "marcas contextualizadoras", comuns em diferentes fronteiras, incluindo símbolos como o guarda, os "coiotes" - raposa, os olhares vigilantes e observadores - e passou a ser, durante a conversa e análise da obra um contexto significativo compartilhado e pertinente para o tema em questão.

Outro momento em que os eventos e sentimentos tipicamente associados à migração emergem fortemente na obra são as passagens em que a família foge de sua terra natal para outro lugar, com fortes pistas sobre uma retirada, deixando para trás muitas lembranças e objetos, materializados nas malas e pacotes que a família carrega. A perda desses objetos materiais observa-se a cada imagem, pois eles vão diminuindo. Assim, a família sai com várias malas e ao longo do caminho a bagagem vai minguando até que a sequência finaliza, no último transporte, com praticamente nenhuma bolsa, conforme podemos observar nas figuras 4, 5, 6 e 7 . 
Figuras 4, 5, 6 e 7: Fuga.
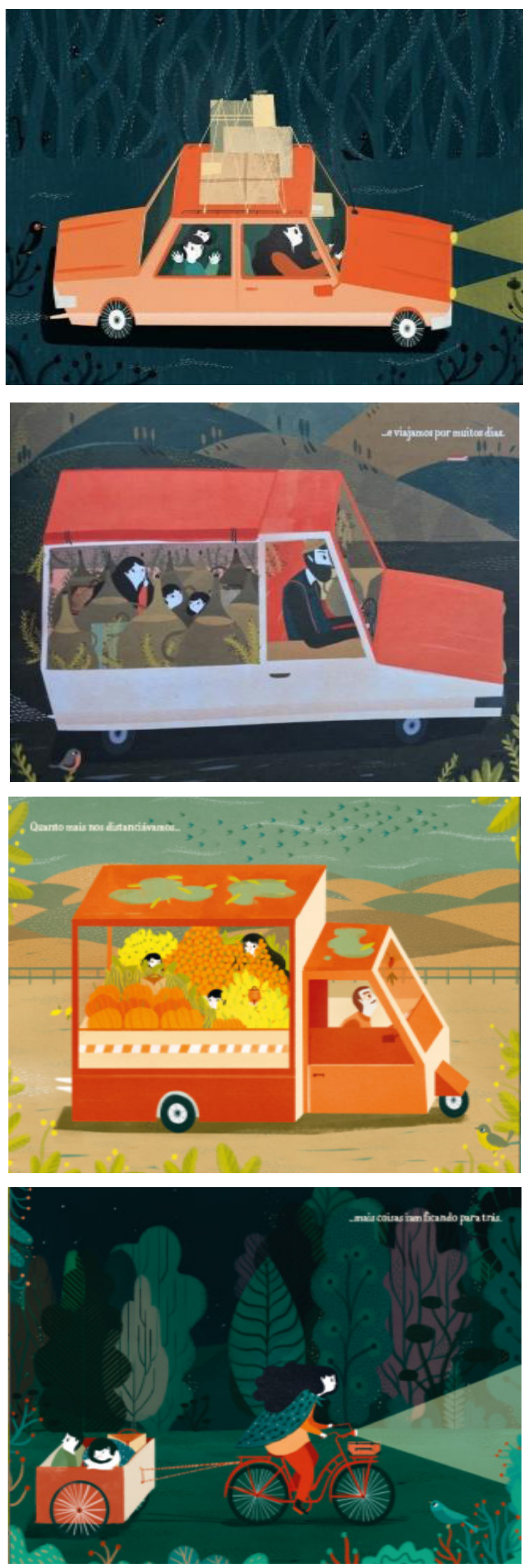

Fonte: SANNA (2016, p. 19-21)
Os referenciais culturais e estéticos mobilizados nas imagens da obra em análise evidenciam a preocupação da autora com o tema em questão. $\mathrm{O}$ processo da migração é apresentado por meio de símbolos de perdas, elementos que marcam fugas velozes e camufladas. Nesse sentido, podemos destacar o papel do leitor nesse processo de compreensão leitora, pois essa prática é "mediada também nos contextos político-econômico e ou histórico-culturais dos leitores, o qual constrói sentido, a partir da sua própria identidade." (THIÉL, 2013, p. 1187). Nesse caso, a situação da "fuga", que remete a um contexto político-econômico distante dos alunos, devido à situação de guerra civil vivenciada pelas personagens, acaba por não parecer, no entanto, tão remota, quando se pensa na vida nômade que alguns alunos dessa pesquisa vivenciam, no momento em que suas famílias precisam fazer uma saída do lugar de pertencimento em razão do tráfico, da insegurança ou do desemprego. $\mathrm{Na}$ conversa realizada com os alunos, observam-se essas questões.

Assim, anteriormente à leitura compartilhada, os alunos foram solicitados a verbalizar que associações faziam à palavra viagem. Nas falas abaixo, os alunos associaram a palavra viagem a uma questão de mudança.

\section{P. 1: A gente já falou várias...}

A4(o): Ah! Eviagem também me lembra uma coisa: mudança!

Professora: Por quê?

A4(o): Porque vai mudando de lugar..

A25: Porque tem que arrumar as coisas pra depois ir!

Podemos observar que viajar, no contexto de vida desses alunos, nem sempre tem uma conotação de lazer, de férias. Viajar parece ser também experiência decorrente do "ter que" se mudar, arrumar as malas e sair. Também compreendem a necessidade de viajar como fuga.

\section{P 1: Viajar porque a gente quer? De férias?}

[vários alunos juntos]: Não!

A2(a): Porque é preciso!

P 1: E por que era preciso?

28(a): Por causa da guerra...

P 1: E essas pessoas que viajam porque são obrigadas, porque tá tendo guerra, tem um nome?

A5(o): Fugitivos? 
É interessante pontuarmos como o enredo ficcional arrebata o leitor para "um tempo e espaço que são diversos dos seus, (re)apresentando mundos e personagens que provocam a identificação, ou não, bem como o alargamento do seu horizonte de expectativas" (DEBUS, 2013, p. 1131). Em A viagem, isso não é diferente. O sentido de "fuga" não é uma construção realizada unicamente a partir da leitura da obra, mas uma relação pragmática que se faz com o contexto desses alunos, cujos grupos familiares muitas vezes precisam sair às pressas, fugir em razão do tráfico, tentando manter o que ainda têm, principalmente a vida. Viajar "porque é preciso", como afirma diz A2(a) no diálogo destacado anteriormente.

Nesse processo de "fuga", muitas coisas são deixadas para trás, malas, lembranças... Quando questionados sobre este tópico, os alunos evidenciam o é deixado para trás e o que fica na memória. Vejamos o excerto dessa conversa:

P 1: O que chamou a atenção de vocês das coisas que eles foram carregando na viagem?

A10(o): Malas!

P 1: E o que eles deixaram pra trás?

A33: O pai deles!

[Vários alunos juntos]: Porque ele tinha morrido

P 1: Mais alguma coisa eles deixaram pra trás?

A6(a): O gato!

A4(o): A casa! Deixaram as lembranças boas...

P 2: As lembranças a gente leva ou a gente deixa?

A10(a): A gente leva, fica na cabeça...

Nesse sentido, é importante advertir que os destaques feitos ao que se perde e ao que fica são marcados não apenas por questões materiais, no caso as malas e pacotes, mas, sobretudo por aspectos mais íntimos, subjetivos, pessoais: "o pai”, "o gato", “as lembranças boas", componentes afetivos e emotivos. Isso se observa também em resposta a uma das atividades de escrita proposta à turma pelos pesquisadores, que será apresentada a seguir.

\section{A OBRA, A LEITURA E AS \\ ATIVIDADES ESCRITAS: ALGUMAS REPRESENTAÇÕES DO COTIDIANO}

Apresentaremos, a seguir, duas atividades propostas no projeto e realizadas pelos alunos após a sessão da leitura.

Em uma primeira atividade, os alunos foram solicitados a produzir um texto considerando os seguintes aspectos: $O$ que aconteceria com a familia descrita no livro, depois que chegassem num lugar onde pudessem ficar seguros? Como recomeçariam sua vida? Os alunos poderiam fazer um desenho ilustrativo do seu texto, após a escrita. Vejamos, a título de exemplo, ${ }^{8}$ o que a aluna T e o. aluno Y escreveram.

Figura 8: Texto da aluna $\mathrm{T}^{9}$

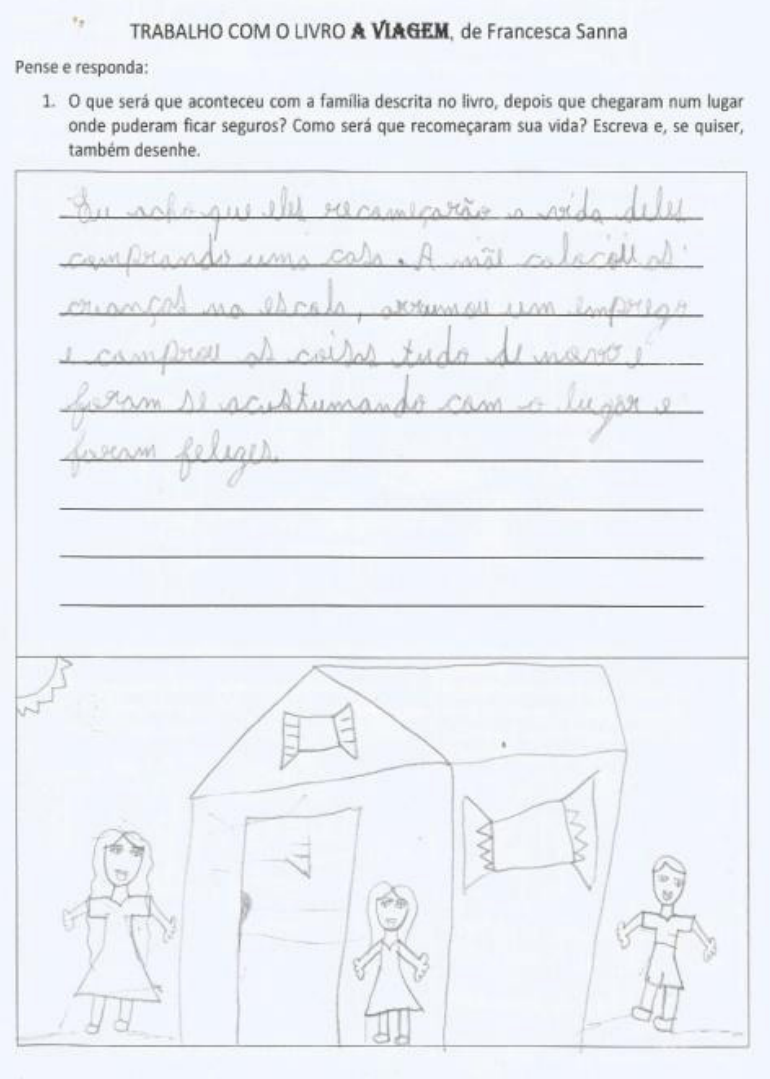

\footnotetext{
${ }^{8}$ Os trabalhos escolhidos, entre os de 12 alunos que efetivamente os entregaram, o foram intencionalmente, em virtude da relevância de suas referências, julgada pelas autoras do artigo. A análise de todos os trabalhos excederia o tamanho e o escopo do presente artigo.

${ }^{9}$ Transcrição do texto da aluna T: Eu acho que eles recomeçarão a vida deles comprando uma casa. A mãe colocou as crianças na escola, arrumou um emprego e comprou as coisas tudo de novo e foram se acostumando com o lugar e foram felizes. (Transcrição sem correção ortográfica e linguística).
} 
Figura 9: Texto do aluno $\mathrm{Y}^{10}$

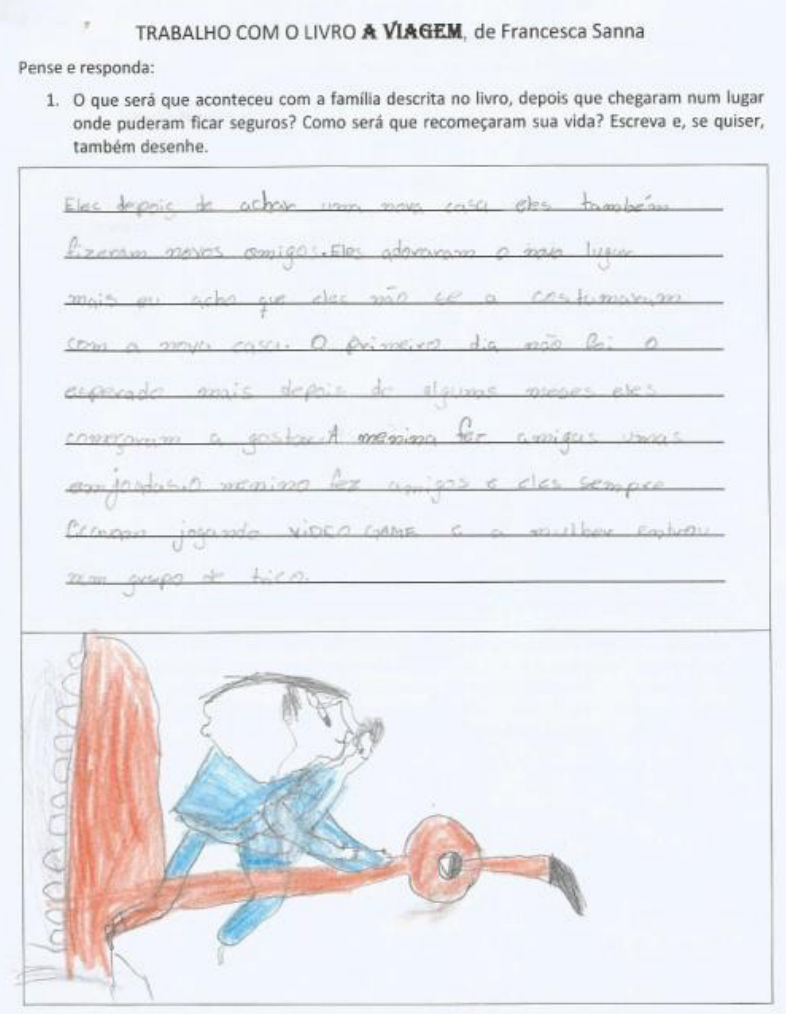

Ao analisarmos esses dois textos, podemos observar como as crianças avaliaram a possibilidade de mudança como algo positivo, talvez com algumas dificuldades no início - "O primeiro dia não foi lá o esperado, mais depois de alguns meses eles começaram a gostar." (Texto do aluno Y). Ambos parecem felizes com a mudança de uma vida nova - "[...] foram se acostumando com o lugar e foram felizes". (Texto da aluna T). "Eles adoraram o novo lugar [...]". (Texto do aluno Y). Nenhum dos dois alunos parece lembrar ou referir as saudades do que as personagens deixaram.

$\mathrm{O}$ aluno $\mathrm{Y}$ encontra possibilidade de novos amigos, utilizando traços socialmente estereotipados de gênero - "A menina fez amigas umas enjoadas, o menino fez amigos e eles ficavam sempre jogando vídeo game [...]". (Texto do aluno Y), e, talvez, de geração - “[...] a mulher entrou num grupo de tricô ". (Texto do aluno Y).

\footnotetext{
${ }^{10}$ Transcrição do texto do aluno Y: Eles também depois de achar uma nova casa eles também fizeram novos amigos. Eles adoraram o novo lugar mais eu acho que eles não se acostumaram com a nova casa. O primeiro dia não foi lá o esperado, mais depois de alguns meses eles começaram a gostar. A menina fez amigas umas enjoadas, o menino fez amigos e eles ficavam sempre jogando vídeo game e a mulher entrou num grupo de "trico". (Transcrição sem correção ortográfica e linguística).
}

Já a aluna T encontra possibilidade de tudo novo: escola, emprego, casa, novas coisas - "A mãe colocou as crianças na escola, arrumou um emprego e comprou as coisas tudo de novo [...]" (Texto da aluna T).

Ao analisarmos essas produções textuais observamos como o contato com obras literárias de contextos diversos e temas polêmicos tem permitido aos alunos o alargamento de horizontes. Os alunos conseguem ver outras possibilidades de recomeços de vida, a partir da "fuga" descrita na obra trabalhada. Dessa forma, o leitor "experiencia um viver distante do seu, ao mesmo tempo tão próximo, e, ao voltar desse encontro ficcional, já não é o mesmo, ele é capaz de reconfigurar seu viver". (DEBUS, 2013, p.1131).

Nesse sentido, vale destacar um excerto de Larrosa (2002) sobre a experiência, uma vez que a proposta literária do "viver como" se fez presente nessa sessão e possibilitou a circulação de vários significados em relação à migração, experiência simultaneamente distante e próxima desse grupo de alunos.

A experiência, a possibilidade de que algo nos aconteça ou nos toque, requer um gesto de interrupção, um gesto que é quase impossível nos tempos que correm, requer parar para pensar, parar para olhar, parar para escutar, pensar mais devagar, olhar mais devagar, e escutar mais devagar, parar para sentir, sentir mais devagar, demorar-se nos detalhes, suspender a opinião, suspender o juízo, suspender a vontade, suspender o automatismo da ação, cultivar a atenção e a delicadeza, abrir os olhos e os ouvidos, falar sobre o que nos acontece, aprender a lentidão, escutar aos outros, cultivar a arte do encontro, [...] ter paciência e dar-se tempo e espaço. (LARROSA, 2002, p.24).

A força dessas vozes no contexto de sala de aula, enunciando olhares sobre a obra, vão suspendendo o automatismo do cotidiano escolar e permitindo a entrada no imaginário, no ficcional da literatura e abrindo a possibilidade de entrar em outros mundos distantes e próximos, considerando o olhar, o detalhe, do olhar, da escuta e da conversa que Francesca Sanna nos permitiu a partir de sua obra, como podemos observar nas falas a seguir, proferidas em superposição e marcadas pelo entusiasmo das descobertas:

\section{A4(o): Eu tô vendo um homem barbudão! \\ A26(a): Um monstro com uma mulher aqui ó...}

2(a): Parece que eles tão arrumando as malas e parece que eles são chineses...

A27(a): E aqui tem duas mãos... 
A28(a): Tem três pessoas correndo, aqui!

A10(o): Uma coruja!

A29(o): Pássaros...

A5(o): Parece que tem duas mãos aqui!

A29(o): Ô sora, um barco!

A16(o): Um monstro com a boca aberta...

A6(a): Esse monstro é grandão, ele tá com as mãos até lá embaixo!

A4(o): O monstro é dois!

Assim, o que observamos não são apenas enunciações, vozes, falas, mas uma arena de significados, "orquestrados" pelas negociações realizadas durante as conversas sobre a obra.

Numa segunda atividade, solicitou-se que os alunos escolhessem, desenhassem e nomeassem objetos que levariam numa "fuga", a partir de três quadros. No quadro 1 deveriam escolher dez coisas (podendo incluir animais...) que levariam em sua viagem. No quadro 2, deveriam deixar a metade das coisas pelo caminho, devendo escolher, portanto, cinco coisas que levariam consigo. E, para o quadro 3, deveriam escolher apenas uma coisa (ou animal) e escrever o porquê da escolha. Vejamos as escolhas dos alunos Y e L.

Figura 10: Trabalho escrito de $\mathrm{Y}^{11}$

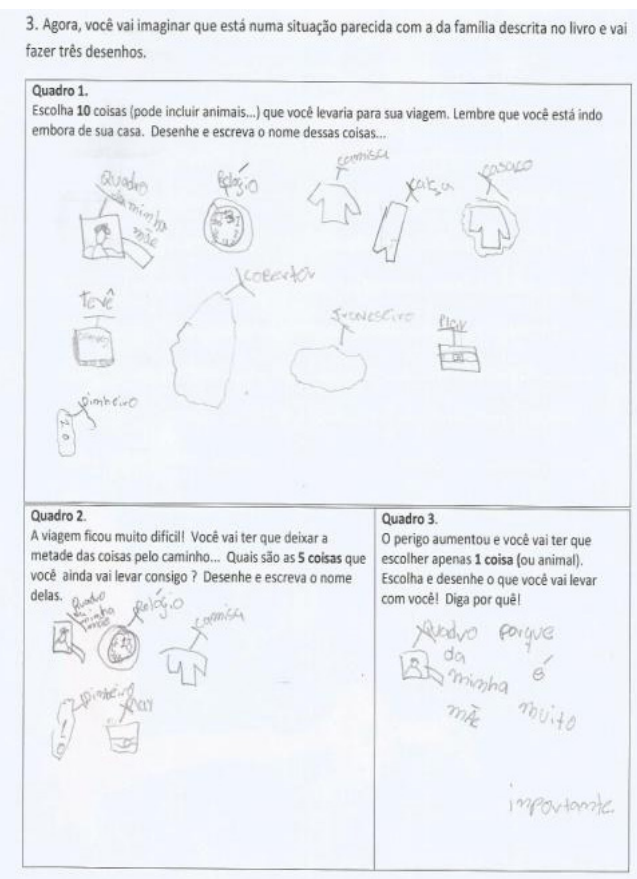

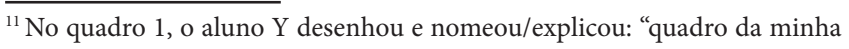
mãe" [porta retrato], "relógio, camisa, calça, casaco, tevê, cobertor, travesseiro, play, dinheiro". No quadro 2: quadro da mãe (porta retrato), relógio, camisa, play e dinheiro. E no quadro 3: quadro da mãe "porque é muito importante".
Figura 11: Trabalho escrito de $\mathrm{L}^{12}$

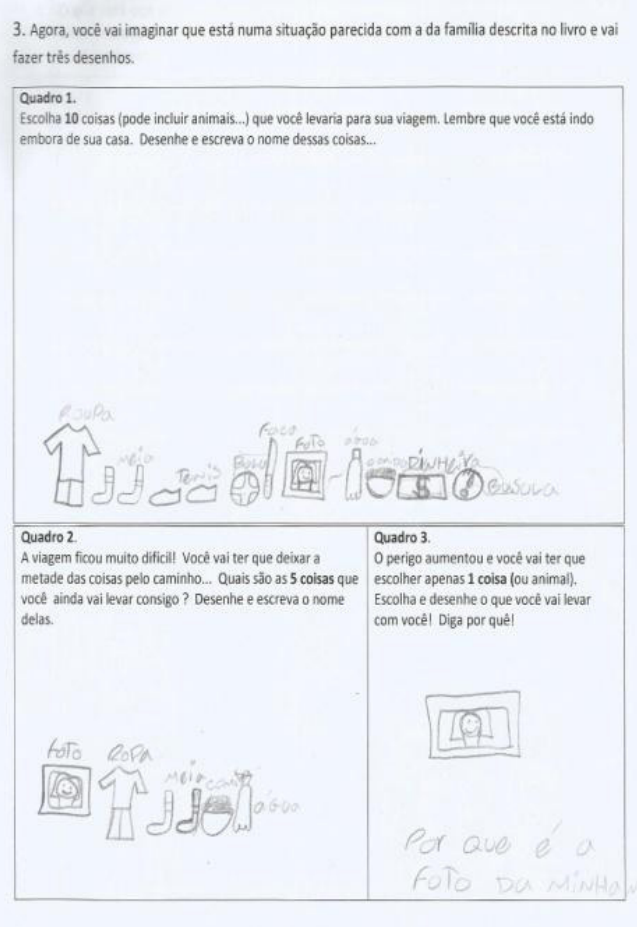

Entre os objetos escolhidos pelo aluno Y e o aluno L aparecem elementos de lazer da infância como a bola, o "play" e a "tevê" ${ }^{13}$, peças de vestuário: calça, camisa, casaco, meia, tênis. Aliás essa questão do vestuário chama a atenção em muitos trabalhos, pois quase todos os alunos escolheram peças de vestuário e abrigo que pudessem esquentá-los, como casaco, luva, touca etc. Os dois alunos autores dos trabalhos acima escolhem dinheiro e o porta-retrato com foto ou só foto da mãe. $\mathrm{O}$ aluno $\mathrm{Y}$ escolhe também um cobertor e um travesseiro, além de um relógio. E o aluno L escolhe comida, água - objetos presentes em muitos outros trabalhos, além de uma faca e uma bússola (no caso, sugerindo a consciência de um trajeto com mais dificuldades).

Ao definir cinco objetos, o aluno $\mathrm{Y}$ escolheu o "quadro da minha mãe" (porta-retrato), relógio, camisa, play e dinheiro, enquanto o aluno L cita foto, roupa, meia, comida e água. E por último, ambos

\footnotetext{
12 No quadro 1, o aluno L, desenhou e nomeou: roupa, meia, tênis, bola, faca, foto, água, comida, dinheiro e bússola. No quadro 2: foto, roupa, meia, comida e água. E no quadro 3: foto, "porque é a foto da minha mãe".

${ }^{13}$ Objetos que compõem o universo infantil contemporâneo urbano, independentemente de maior ou menor poder aquisitivo das famílias das crianças, estiveram muito presentes em todos os trabalhos, não só nesses. Há muitos trabalhos em que, entre as escolhas, são citadas a televisão, o celular, e o "play" (vídeo game). A presença mais generalizada é a da tevê, inclusive com a representação de programas, como a novela "Força do Querer", da rede Globo.
} 
selecionam como último objeto, o "quadro da mãe" (porta-retrato), porque "é muito importante", e a foto, porque é a "foto da mãe". Nesse sentido, observamos que as escolhas do aluno $Y$ e do aluno L são marcadas por uma dimensão bastante emotiva, uma vez que suas mães são falecidas. $\mathrm{O}$ travesseiro parece também um objeto bastante pessoal. Assim, as predileções do aluno $\mathrm{Y}$ e do aluno L são escolhas que dizem respeito às suas experiências de vida, articuladas às experiências da leitura. Afinal, "a leitura de cada leitor é modulada pelas suas experiências de vida incluindo, neste rol, seus afetos, suas incertezas, seus dilemas cotidianos". (DALLA ZEN; SILVEIRA, 2013, p.55).

Figura 12: Trabalho escrito de $\mathrm{K}^{14}$

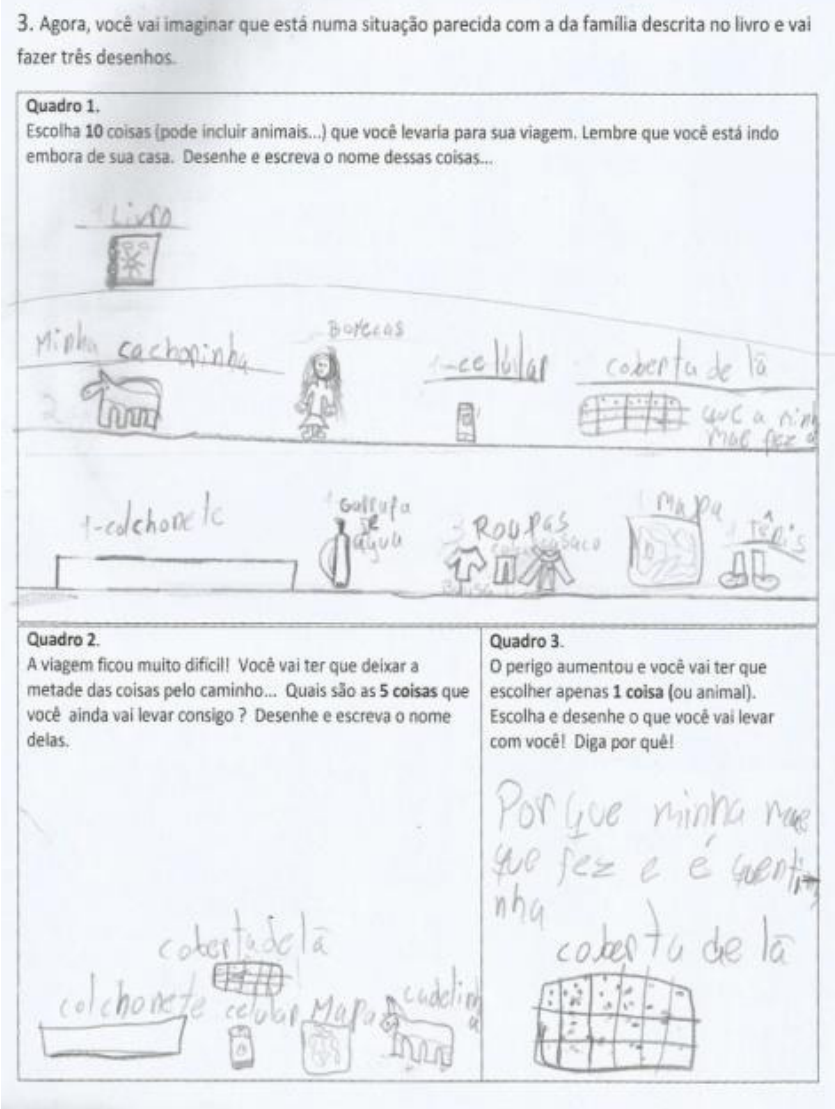

Outro trabalho que destacamos em razão de motivações afetivas para a escolha dos elementos é o elaborado pela aluna K. Em um primeiro momento, ela afirma que levaria um livro ${ }^{15}$, sua cachorrinha,

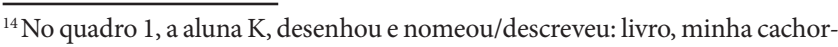
rinha, boneca, celular, coberta de lã, colchonete, garrafa de água, roupas, mapa e tênis. No quadro 2: minha cachorrinha, celular, coberta de lã, colchonete, e mapa. E no quadro 3: Coberta de lã, "porque foi a mãe quem fez e é quentinha".

${ }^{15} \hat{E}$ interessante pontuar que objetos escolares aparecem apenas nas
}

bonecas, celular, coberta de lã, colchonete, garrafinha de água, roupas, mapa e tênis. Num segundo momento (tendo que abandonar cinco elementos), mantém colchonete, coberta de lã, celular, mapa, cachorrinha, e, por último, quando precisa escolher apenas 1 elemento, seleciona a coberta de lã e explica: "minha mãe que fez e é quentinha". Nesse trabalho, dois elementos afetivos se destacam: a cachorrinha e a coberta de lã feita pela mãe da aluna.

Ao selecionarmos esses trabalhos, entre outros possíveis, desejamos apontar como a leitura e discussão dessa obra permitiram que se manifestassem contextos marcados pelas condições históricas concretas desses alunos, que vivem em situação de vulnerabilidade social e, em algumas situações, passando frio e fome. Portanto a comida ${ }^{16}$, as roupas quentes, a coberta de lã, considerando o clima de alguns períodos do ano na região Sul em que os alunos moram, são elementos importantes de sobrevivência. Também visualizamos, nos trabalhos das crianças, referências à perda de membros familiares importantes, como a mãe, o que de algum modo se vinculou ao tema da viagem e da falta.

Assim, nesses encontros dialógicos com a leitura desdobram-se e se produzem sentidos para aquilo que somos e para o que pensamos que são os "outros", neste caso, os migrantes. Tal como afirma Canclini (2016, p. 51), é evidente que os encontros com os "outros" geram conflitos e nos colocam em certo desconforto, mas eles são vitais para imprimir dinamismo aos nossos pontos de vista. "Fazemos experiências fronteiriças permanecendo em nosso lugar natal. E, por sua vez, pensar, sentir e imaginar considerando apenas lugares particulares desautoriza os discursos magistrais que pretendem ser válidos para o mundo". Vivemos, conforme o autor, uma interculturalidade difusa e aberta - são incomuns os lugares restritos apenas aos habitantes locais, espaços que congregam pessoas de uma só proveniência, localidades que não sejam híbridas. Assim, devemos nos ocupar das zonas de intercâmbio, e entendemos que a literatura pode ser uma inspiradora forma deste "ocupar-se" dos outros.

\footnotetext{
representações feitas pelas meninas, geralmente no quadro 1, das dez primeiras escolhas, e depois desaparecem.

${ }^{16} \mathrm{Em}$ um dos trabalhos, além de selecionar a comida como algo importante a ser levado na "fuga," o aluno escolhe objetos onde se prepara a comida, selecionando fogão, microondas e uma mesa. Talvez estivesse preocupado em onde cozinhar.
} 


\section{CONSIDERAÇÕES FINAIS}

Em primeiro lugar, em relação aos livros sobre a temática migração analisados na parte inicial deste artigo, podemos fazer algumas aproximações aos achados da análise da coletânea de livros disponíveis na Espanha (COLOMER; FITTIPALDI, 2012). Assim, é comum, também nas obras que circulam no Brasil, a predileção pela narrativa em $1^{\mathrm{a}}$ pessoa, como um recurso potente para a identificação do leitor com as situações apresentadas, ou pela utilização do narrador onisciente que focaliza o protagonista migrante. $\mathrm{O}$ "catálogo de males" causadores da migração, referidos pelas autoras, como guerras, secas, conflitos, perseguições, fome, apresenta-se mais econômico nas obras que circulam no Brasil (em sua maioria, voltadas ao pequeno leitor e com pouco texto). Contudo, os paratextos de algumas dessas obras tratam de contextualizar e inserir o leitor no panorama sobre as ondas migratórias que ocorrem em distintos pontos do globo. Por outro lado, assim como os livros analisados pelas autoras espanholas (a cuja lista não se tem acesso), as obras aqui disponíveis também se integram num quadro de atitudes positivas e de acolhimento aos migrantes, sem, entretanto, deixar de mencionar - sob um acento poético e/ou dramático - as dificuldades, os sentimentos, as expectativas e as dores dos migrantes.

Para finalizar, vale destacar que, de nossa perspectiva, temas considerados polêmicos e desafiadores deveriam ser abordados com crianças e jovens, por meio de obras literárias e de um trabalho produtivo de leitura em sala de aula, pois estas possibilitam aos alunos a expressão de sentimentos e a produção de sentidos que têm relação com seu cotidiano. Concordamos com Paiva (2008) quando afirma que não é preciso que o leitor seja sofisticado para que sinta, se comova, encontre pontos de contato com dramas vividos por outras pessoas - ainda que se distanciem de seus próprios. Para a autora, a literatura pode permitir experimentar esteticamente alguns destes sentidos e, desse modo, o leitor poderá entender o drama narrado (e os vividos) dentro de um quadro mais amplo de referências.

Argumenta-se, enfim, que tais temas carregam uma força humanizadora, considerando que "um drama humano enquanto uma forma emblemática de existência é surpreendente e, assim, epifânico porque ocorre apesar do esforço de superação (ou não) de quem o vive mergulhado em adversidades que não controla (e, por isso, nunca é algo previsível)" (PAIVA, 2008, p. 45). Podemos nos identificar com tramas e dramas na medida em que eles nos são apresentados nas narrativas que se espraiam por nosso cotidiano ou nas narrativas literárias que nos chegam. Podemos nos colocar frente a um texto "como se", para experimentar esses plurais lugares que as narrativas fazem emergir.

Assim sendo, abordar temas e problemas humanos daqueles que migram em busca de uma vida melhor, ou, ainda, daqueles que fogem tentando manter a vida e seguir com ela em outros lugares, expor as complexidades das travessias daqueles que transitam entre fronteiras, de forma clandestina, com pequenos afagos e fortuitos espaços de aconchego, com breves pontos de ancoragem, é uma das possibilidades abertas pelo texto literário. Diálogos travados ao longo da leitura interativa e trabalhos realizados pelos alunos, no âmbito da presente pesquisa, permitem pensar nas reverberações da temática das migrações e no modo como, na dureza e sensibilidade deste tipo de história narrada, algo pode acontecer a alunos, professores, leitores, algo pode se dar, em termos de experiência. Talvez seja preciso ler sutilmente, vagarosamente, tanto os textos literários sobre temas como migrações, quanto as produções derivadas destas leituras, para perceber a cadência desses textos e a poética dessas vidas que falam de si mesmas e falam de nós.

As palavras de Manoel de Barros nos ajudam a fechar esse percurso, colocando ênfase na noção de que as palavras (literárias e poéticas) nos permitem ser com outros e, quem sabe, observar a paisagem do ponto de vista de borboletas e aves migratórias.

A maior riqueza do homem é sua incompletude. Neste ponto sou abastado.

Palavras que me aceitam como sou - eu não aceito. Não aguento ser apenas um sujeito que abre portas, que puxa válvulas, que olha o relógio, que compra pão às 6 horas da tarde, que vai lá fora, que aponta lápis, que vê a uva etc. etc.

Perdoai

Mas eu preciso ser Outros.

Eu penso renovar os homens usando borboletas.

(BARROS,2002 p.79) 


\section{REFERÊNCIAS}

BARROS, Manoel de. Retrato do artista quando coisa. 3 . ed. Rio de Janeiro: Record, 2002.

BUITRAGO, Jairo. Eloísa e os bichos. Ilustrações de Rafael Yochteng. São Paulo: Editora Pulo do Gato, 2013.

BUITRAGO, Jairo. Para onde vamos. Ilustrações de Rafael Yochteng. São Paulo: Editora Pulo do Gato, 2016.

BURKE, Peter. Perdas e ganhos - exilados e expatriados na história do conhecimento na Europa e nas Américas, 15002000. São Paulo: Editora UNESP, 2017.

CADEMARTORI, Ligia. Para não aborrecer Alice: a ilustração no livro infantil. In: PAIVA, Aparecida; SOARES, Magda (orgs.). Literatura infantil: políticas e concepções. Belo Horizonte: Autêntica, 2008, p. 79-90.

CANCLINI, Néstor Garcia. O mundo inteiro como lugar estranho. São Paulo: Editora da Universidade de São Paulo, 2016.

CHAMBERS, Aidam. Dime. Espacios para la lectura. Mexico: Fondo de Cultura Economica, 2007.

COGO, Denise. Migrações contemporâneas como movimentos sociais: uma análise desde as mídias como instâncias de emergência da cidadania dos migrantes. Revista Fronteiras - Estudos Midiáticos, vol. IX n ${ }^{\circ} 1$ - jan/abr, 2007, p. 64-73.

COLOMER, Teresa; FITTIPALDI, Martina (eds.) La literatura que acoge: inmigración y lectura de albumes. Barcelona: Banco del Libro - GRETEL, 2012.

COLOMER, Teresa. La literatura que acoge; um proyecto de investigación en las aulas. In: COLOMER, Teresa; FITTIPALDI, Martina (eds.) La literatura que acoge: inmigración y lectura de albumes. Barcelona: Banco del Libro - GRETEL, 2012. P.7-25.

DALLA ZEN, Maria Isabel H.; SILVEIRA, Rosa Maria H. Surpresa, captura e envolvimento. Literatura Infantil. São Paulo: Segmento, 2013, p. 50-61.

DEBUS, Eliane Santana Dias. A literatura Angolana para infância. Educação \& Realidade, v. 38, n. 4 (out./dez). Porto Alegre: Universidade Federal do Rio Grande do Sul, 2013, p. 1129-1145.

GARLAND, Sarah. Um outro país para Azzi. São Paulo: Editora Pulo do Gato, 2012.

LARROSA, Jorge. Notas sobre a experiência e o saber da experiência. Revista Brasileira de Educação, n ${ }^{\circ}$ 19, jan.-abr. 2002. P. 20-28.

MATEO, José Manuel. Migrar. Ilustrações de Javier Martínez Pedro. São Paulo: Editora Pallas, 2013.

MATEOS, Mariana Chiesa. Migrando. São Paulo: Editora 34, 2015.
PAIVA, Aparecida. A produção literária para crianças: onipresença e ausência de temáticas. In: PAIVA, Aparecida; SOARES, Magda (orgs.). Literatura infantil: políticas e concepções. Belo Horizonte: Autêntica Editora, 2008, p. 3552.

SANNA, Francesca. A Viagem. São Paulo, SP: Vergara e Riba, 2016.

SILVEIRA, Rosa Maria Hessel. A polifonia na sala de aula: um estudo do discurso pedagógico. Tese de doutorado. Porto Alegre: UFRGS/FACED, 1995.

THAN, Shaun. A chegada. São Paulo: Edições SM, 2011.

THIÉL, Janice Cristine. A literatura dos povos indígenas e a formação do leitor multicultural. Educação \& Realidade, v. 38, n. 4 (out./dez). Porto Alegre: Universidade Federal do Rio Grande do Sul, 2013, p. 1175-1190 